Article

\title{
Stem Cell Enrichment with Selectin Receptors: Mimicking the pH Environment of Trauma
}

\author{
Thong M. Cao ${ }^{1, \dagger}$, Michael J. Mitchell ${ }^{1, \dagger}$, Jane Liesveld ${ }^{2}$ and Michael R. King ${ }^{1, *}$ \\ 1 Department of Biomedical Engineering, Cornell University, Ithaca, NY 14850, USA; \\ E-Mails: tc436@cornell.edu (T.M.C.); mjm529@cornell.edu (M.J.M.) \\ 2 School of Medicine and Dentistry, University of Rochester Medical Center, Rochester, NY 14642, \\ USA; E-Mail: jane_liesveld@urmc.rochester.edu \\ $\dagger$ These authors contributed equally to this work. \\ * Author to whom correspondence should be addressed; E-Mail: mike.king@cornell.edu; \\ Tel.: +1-607-255-9803; Fax: +1-607-255-7330.
}

Received: 16 July 2013; in revised form: 6 September 2013 / Accepted: 11 September 2013 / Published: 17 September 2013

\begin{abstract}
The isolation of hematopoietic stem and progenitor cells (HSPCs) is critical for transplantation therapy and HSPC research, however current isolation techniques can be prohibitively expensive, time-consuming, and produce variable results. Selectin-coated microtubes have shown promise in rapidly isolating HSPCs from human bone marrow, but further purification of HSPCs remains a challenge. Herein, a biomimetic device for HSPC isolation is presented to mimic the acidic vascular microenvironment during trauma, which can enhance the binding frequency between L-selectin and its counter-receptor PSGL-1 and HSPCs. Under acidic pH conditions, L-selectin coated microtubes enhanced CD34+ HSPC adhesion, as evidenced by decreased cell rolling velocity and increased rolling flux. Dynamic light scattering was utilized as a novel sensor to confirm an L-selectin conformational change under acidic conditions, as previously predicted by molecular dynamics. These results suggest that mimicking the acidic conditions of trauma can induce a conformational extension of L-selectin, which can be utilized for flow-based, clinical isolation of HSPCs.
\end{abstract}

Keywords: CD34+ hematopoietic stem cells; L-selectin; biomimetic; acidic pH 


\section{Introduction}

Human hematopoietic stem and progenitor cells (HSPCs) originating from the bone marrow (BM) play a critical role in treating many hematological malignancies due to their unique multipotent, stem cell quality [1,2]. In cancer patients with depleted immune cells, HSPCs transplantation is used to repopulate blood cell lineages [3,4]. On the other hand, increasing evidence has shown that mutagenesis which occurs during the development of HSPCs converts these cells to leukemic stem cells [5,6]. Therefore, a reliable and simple means for the acquisition and enrichment of HSPCs for both transplantation therapy and to better understand leukemia is needed.

HSPCs routinely leave the BM to enter the circulatory system and distant tissues to establish and maintain hematopoiesis [7-10]. During embryogenesis, HSPCs migrate to the fetal liver and differentiate [11-13]. In adults, HSPCs participate in the innate immune response against foreign antigens [14-16]. HSPCs express a repertoire of surface ligands that include unique markers as well as markers shared with leukocytes and circulating tumor cells [17,18] that can bind the family of adhesion molecules called selectins (E-, L- and P-), which facilitates their migration from (and to) the BM and distant tissues [19-23]. In a recent study, we observed that acidic extracellular $\mathrm{pH}$ enhances L-selectin:PSGL-1 interactions under flow [24]. Extracellular $\mathrm{pH}$ becomes acidic during the early stages of wound healing and inflammation [25,26], which is also a period of elevated recruitment of HSPCs to target sites [27,28]. It follows that HSPCs may experience altered adhesion due to L-selectin:ligand binding in acidic environments.

In this study, we determined that L-selectin ligands expressed on the surface of HSPCs bind with enhanced affinity to L-selectin under acidic extracellular pH. Furthermore, the enhanced L-selectin:ligand binding affinity is due to L-selectin undergoing conformational change in acidic $\mathrm{pH}$ as quantified by dynamic light scattering measurements of selectin-PEG-decocorated liposomes. Finally, by mimicking this physiological phenomenon, we demonstrate its potential use to capture and enrich HSPCs by perfusing a suspension of BM cells through L-selectin coated microtubes under acidic $\mathrm{pH}$.

\section{Experimental Section}

\subsection{Reagents and Antibodies}

Phosphate-buffered saline (PBS) and Hank's balanced salt solution (HBSS) were purchased from Invitrogen (Grand Island, NY, USA). Recombinant human P-, L-, and E-selectin/IgG chimera were purchased from R\&D Systems (Minneapolis, MN, USA). Phycoerythrin (PE)-conjugated mouse anti-human CD34 (clone 581) and PE-conjugated mouse IgG1 $\kappa$-isotype control were purchased from Biolegend (San Diego, CA, USA). APC-conjugated mouse anti-human L-selectin (clone DREG-56) was purchased from BD Biosciences (San Jose, CA, USA).

\subsection{Isolation of Bone Marrow Cells}

Bone narrow mononuclear cells (MNCs) were extracted from consenting adult donors following a protocol approved by the Research Subjects Review Board of the University of Rochester, as described previously [22]. Briefly, bone marrow samples were diluted 3 -fold (vol/vol) in $\mathrm{Ca}^{2+}$ and 
$\mathrm{Mg}^{2+}$-free PBS, with $35 \mathrm{~mL}$ of the diluted sample carefully layered over $15 \mathrm{~mL}$ Ficoll cell separation solution (GE Healthcare, Piscataway, NJ, USA) in $50 \mathrm{~mL}$ Falcon tubes. Samples were then centrifuged at $800 \mathrm{~g}$ for $20 \mathrm{~min}$ at RT to separate bone marrow MNCs from excess cells and tissue debris. The buffy coat of MNCs was extracted and place into a separate tube and washed twice in PBS. Bone marrow MNCs were quantified and placed in flow buffer (PBS supplemented with $\mathrm{Ca}^{2+}$ ) for flow-based assays.

\subsection{Isolation of CD34+ Population using Microbeads}

To characterize the rolling characteristics of CD34+ HSPCs in acidic $\mathrm{pH}$, CD34+ bone marrow HSPCs were isolated using EasySep Human CD34 Positive Selection Kit by StemCell Technology (Vanvouver, BC, Canada) per manufacturer's instructions. Briefly, a solution of mononuclear cells was incubated with tetrameric antibody complexes against CD34 for $15 \mathrm{~min}$, followed by incubation with dextran-coated magnetic nanoparticles (MNP) for $10 \mathrm{~min}$. The cell-containing tube was then placed in an EasySep ${ }^{\circledR}$ magnet for positive selectin, allowing the MNP-conjugated CD34+ cells to remain in the tube while the supernatant was poured off. The cell population was washed and the magnetic separation was repeated until the desired purity was achieved.

\subsection{Microtube Functionalization}

Micro-renathane (MRE) tubes (300 $\mu \mathrm{m}$ inner diameter, $50 \mathrm{~cm}$ long; Braintree Scientific, Braintree, MA, USA) were sterilized with $80 \%$ ethanol for 10 min. The tubes were then washed $(3 \times)$ with PBS buffer $\left(\mathrm{Ca}^{2+}\right.$-free). The inner surface was functionalized with recombinant human $\mathrm{L}$-selectin/Fc at specified concentration for $2 \mathrm{~h}$. The microtubes were then incubated in PBS supplemented with dry milk (5\% $w / v$; Sigma-Aldrich, St. Louis, MO, USA) for $1 \mathrm{~h}$ to prevent nonspecific adhesion. All steps were performed at room temperature (RT). In several experiments microtubes were labeled with APC conjugated mouse anti human L-selectin for $30 \mathrm{~min}$. Microtubes were washed three times with buffer and images were acquired on an inverted research microscope (Olympus America, Melville, NY, USA).

\subsection{Flow-Based Cell Adhesion Assay}

Cells suspended in PBS buffer (supplemented with $2 \mathrm{mM} \mathrm{Ca}^{2+}$ ) at a specified $\mathrm{pH}$ (6.6 or 7.4) were perfused through functionalized microtubes using a syringe pump at a wall shear stress of 2.0 dynes (dyn) $/ \mathrm{cm}^{2}$. Videos of rolling cells were captured and analyzed using ImageJ (US National Institutes of Health, Bethesda, MD, USA). Cell rolling velocity was determined by measuring the displacement of a rolling cell over time, while rolling flux was determined by quantifying the number of rolling cells entering the image frame over the course of $1 \mathrm{~min}$.

\subsection{CD34+ HSPC Flow-Based Isolation}

A cell suspension of bone marrow MNCs $\left(5 \times 10^{6}\right.$ cell $\left./ \mathrm{mL}\right)$ in PBS buffer (supplemented with $2 \mathrm{mM}$ $\mathrm{Ca}^{2+)}$ at specified $\mathrm{pH}$ was perfused through L-selectin functionalized microtubes at a wall shear stress of $1.0 \mathrm{dyn} / \mathrm{cm}^{2}$. To collect captured cells, the microtube was incubated with fresh PBS buffer $\left(\mathrm{Ca}^{2+}\right.$ free and supplemented with $2 \mathrm{mM}$ of EDTA) for $15 \mathrm{~min}$, and then the cell gently collected into a $1.5 \mathrm{~mL}$ 
Eppendorf tube. Captured cells were also detached from the surface via air embolism. An air bubble is introduced into the microtube using an empty syringe. The bubble is then slowly pushed through the entire length of the microtube to dislodge any remaining captured cells into the collecting tube at the opposing end.

\subsection{Preparation of Selectin-Conjugated Liposomes}

Multilamellar liposomes were prepared using a thin lipid film hydration method as previously described [29,30]. Briefly, lipids were hydrated in $125 \mathrm{mM}$ ammonium sulfate (Sigma-Aldrich) to form multilamellar liposomes, followed by 10 freeze-thaw cycles and then extrusion as previously described [31,32] to prepare unilamellar liposomes. Recombinant human E-, L-, and P-selectin/Fc chimera ( $\mathrm{rhE} / \mathrm{Fc}$ ) (R\&D Systems, Minneapolis, MN, USA) was conjugated to 1,2-distearoyl-sn-glycero-3-phosphoethanolamine-N-maleimide 2000 (DSPE-PEG2000 maleimide) (Avanti Polar Lipids, Alabaster, AL, USA) via thiolation, and PEG or selectin-PEG conjuguates were covalently attached to diluted unilamellar liposomes as described previously [33]. All liposomes were stored at $4{ }^{\circ} \mathrm{C}$ for no more than one week until usage.

\subsection{Dynamic Light Scattering}

To detect changes in selectin protein conformation, freshly prepared selectin-conjugated liposomes $(<24 \mathrm{~h})$ were diluted $(1,000 \times)$ in buffer at specified $\mathrm{pH}$. To remove aggregates, samples were filtered through a $0.45 \mu \mathrm{m}$ filter (MicroLiter Analytical Supplies, Inc., Suwanee, GA, USA). Samples were analyzed for changes in particle size and polydispersity index (PDI) using a Malvern Zetasizer Nano-ZS (Malvern, Worcestershire, UK).

\subsection{Flow Cytometry}

Isolated cells were stained with mouse anti-human CD34 (clone 581), or mouse IgG1 к-isotype purchased from Biolegend (San Diego, CA, USA). Cells were washed twice with PBS (supplemented with $1 \%$ BSA) and then incubated with antibody at $4{ }^{\circ} \mathrm{C}$ for $30 \mathrm{~min}$. Cells were washed twice with buffer and analyzed using a Guava EasyCyte flow cytometer (Millipore, Billerica, MA, USA). CD34+ post-isolation cell populations were quantified and plotted using FlowJo software (Treestar Inc., San Carlos, CA, USA).

\subsection{Statistical Analysis}

Cell rolling velocity and flux were plotted and statistically analyzed using Prism (GraphPad Software, San Diego, CA, USA). Two-tailed unpaired $t$-test was used to determine statistical significance.

\section{Results and Discussion}

\subsection{CD34+ Human BM Cell Interaction with L-Selectin is Enhanced under Acidic Extracellular pH}

To characterize the influence of acidic extracellular $\mathrm{pH}$ on the interaction of human HSPCs and L-selectin, CD34+ cells were perfused through microtubes coated with L-selectin (Figure 1A) at $2 \mathrm{dyn} / \mathrm{cm}^{2}$. This level of shear stress was chosen because it is within the physiological shear stress 
range that mononuclear cells experience in the human circulatory system. CD34+ cells exhibited a significantly lower rolling velocity on L-selectin under acidic conditions (Figure 1D), when compared to L-selectin mediated CD34+ cell rolling at a $\mathrm{pH}$ of 7.4. At $\mathrm{pH} 6.6, \mathrm{CD} 34+$ cells had an average rolling velocity of $22.14 \pm 1.87 \mu \mathrm{m} / \mathrm{s}$, compared to an average rolling velocity of $31.24 \pm 3.23 \mu \mathrm{m} / \mathrm{s}$ at $\mathrm{pH}$ 7.4. This indicates that under acidic conditions, CD34+ HSPCs experience enhanced binding to L-selectin. To show that the observed interaction between the perfused cells and the coated microtube is L-selectin:ligand specific, cells were perfused through microtubes coated with milk alone. Cell adhesion was not observed in this case (Figure 1B). In contrast, microtubes coated with L-selectin showed extensive cell rolling and adhesion (Figure 1C). In addition, $\mathrm{Ca}^{2+}$-dependent cell rolling [34,35] was abrogated by perfusion with HBSS ( $\mathrm{Ca}^{2+}$ free buffer supplemented with $2 \mathrm{mM}$ EDTA) (data not shown) thus confirming that cell interaction was mediated specifically by L-selectin:ligand adhesion. The average rolling velocity of CD34+ cells was significantly lower compared to MNCs from bone marrow (Figure 1E). This observation supports previous work, which suggested that CD34+ cells have stronger binding affinity to L-selectin than CD34- cells [36]. In contrast, no significant differences in CD34- cells were observed under physiological and acidic pH conditions (Figure 1E). An increase in cell rolling flux of MNCs in acidic $\mathrm{pH}$ was also found, in comparison to the cell flux measured at physiological $\mathrm{pH}$ (Figure 2). These results suggest that acidic $\mathrm{pH}$ can be utilized to enhance the number of cell interactions with the L-selectin coating, thus improving the number of cells captured.

Figure 1. Enhanced adhesion of CD34+ cells to L-selectin at acidic pH. (A) Relative fluorescence intensity of L-selectin coated and blank microtubes labeled with APC-anti human L-selectin. (B-C) Images of perfused cells interacting with blank or functionalized microtubes, respectively. Scale bars are $100 \mu \mathrm{m}$. (D) Rolling velocity of CD34+ cells under normal (7.4) and acidic (6.6) $\mathrm{pH}$. CD34+ cells at a concentration of $1 \times 10^{6}$ cells $/ \mathrm{mL}$ were perfused through L-selectin coated $(20 \mu \mathrm{g} / \mathrm{mL})$ microtubes at a shear stress of $2.0 \mathrm{dyn} / \mathrm{cm}^{2}$ in buffer at specified $\mathrm{pH}$. (E) Comparison of rolling velocities of CD34+ cells and MNCs (unpaired t-test, error bars indicate standard error of the mean; * $p<0.05$, **** $p<0.0001$; $n=3)$.
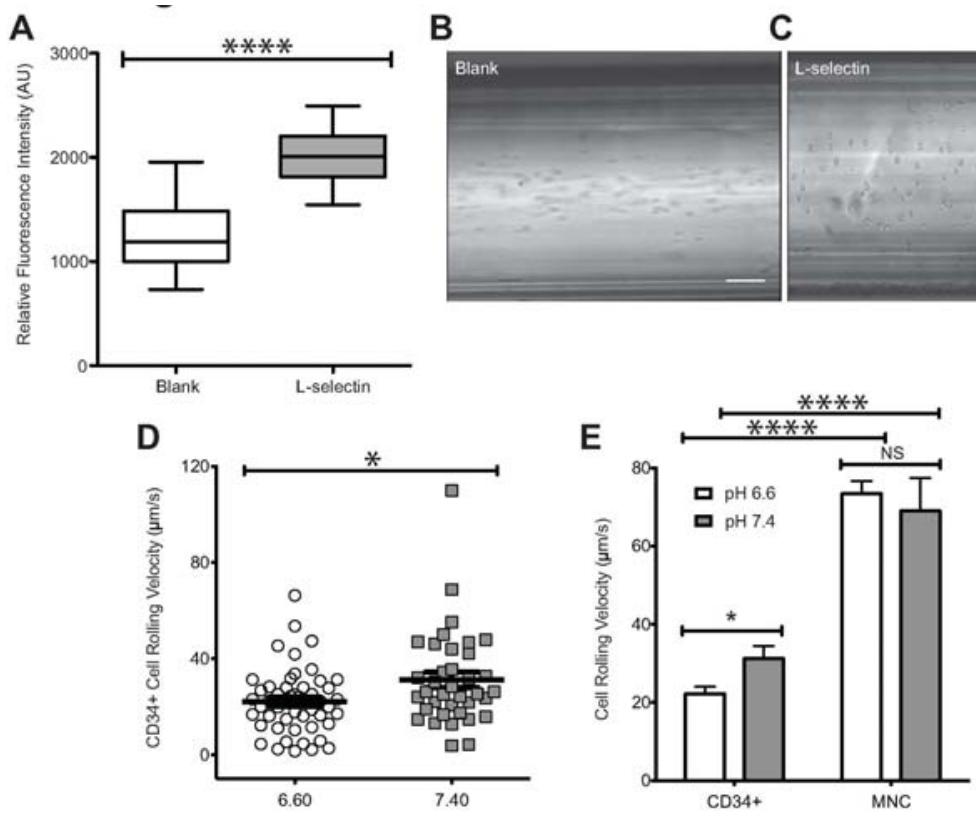
Figure 2. MNCs isolated from bone marrow display higher binding affinity to L-selectin in acidic $\mathrm{pH}$. A suspension of MNCs $\left(1 \times 10^{6}\right.$ cells $\left./ \mathrm{mL}\right)$ was perfused through L-selectin coated $(20 \mu \mathrm{g} / \mathrm{mL})$ microtubes at a shear stress of $2.0 \mathrm{dyn} / \mathrm{cm}^{2}$ in buffer at specified $\mathrm{pH}$. Cell rolling flux was measured by counting the number of rolling cells crossing into the image frame over 1 min (unpaired t-test, error bars indicate standard error of the mean; $* p<0.05 ; n=3)$.

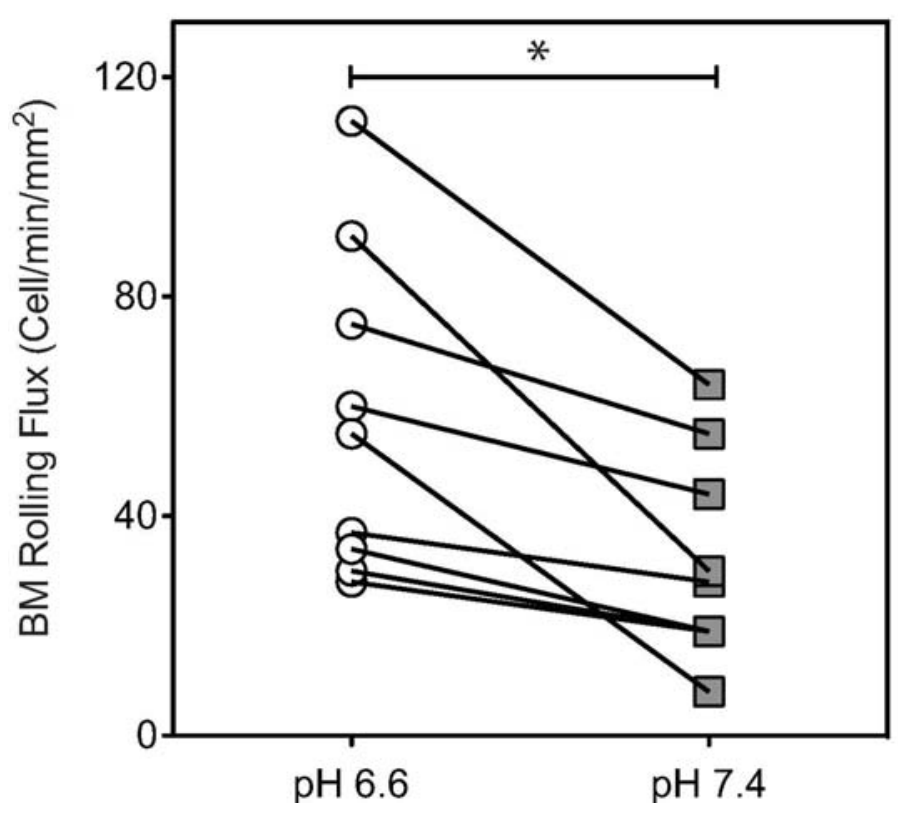

\subsection{Acidic pH Induces Extended Conformation of L-Selectin}

Previous work showed that L-selectin can adopt an "extended" (high affinity) conformation with a point mutation of an amino acid in the EGF domain of L-selectin [37]. This extended conformation results in decreased cell rolling velocity, and an increase in cell flux on the L-selectin ligand PSGL-1. Furthermore, it was previously established that $\mathrm{pH}$ can encourage L-selectin to adopt this extended, high affinity conformation due to the abolition of hydrogen bonding between the EGF and lectin domains of L-selectin which normally confines the protein in the "low affinity" conformation [24]. Therefore, we sought to determine whether acidic $\mathrm{pH}$ can induce a measurable, extended conformation of L-selectin. Dynamic light scattering (DLS) was utilized to determine changes in the protein size of selectins (E, P and L) presented on nanoscale liposomes in buffer at specified $\mathrm{pH}$. While liposomes in the absence of selectin protein (Table 1) or conjugated with E- or P-selectin exhibited minimal, non-significant changes in hydrodynamic radius (Figure 3), L-selectin significantly increased its average length by $1.3 \mathrm{~nm}$ (Figure 3, Table 1) as evidenced by an increase in hydrodynamic radius.

Together, these results indicate that, in comparison to physiological $\mathrm{pH}$, L-selectin can extend its conformation under acidic $\mathrm{pH}$, which is consistent with an observed enhancement in CD34+ cell adhesion. An extended conformation of L-selectin can allow the protein to bind to its ligands more strongly and at higher frequency, as evidenced by a lower CD34+ cell rolling velocity and increased flux (Figure 4). 
Figure 3. Extension of E-, L-, and P-selectin protein size (in nanometers) upon exposure to acidic ( $\mathrm{pH}$ 6.6) conditions. Changes in E-, L-, and P-selectin protein size were determined using dynamic light scattering by subtracting the mean particle radius of selectin-coated liposomes under neutral conditions from the mean particle radius of selectin-coated liposomes under acidic conditions. ${ }^{*} p<0.05 . \mathrm{NS}=$ not significant.

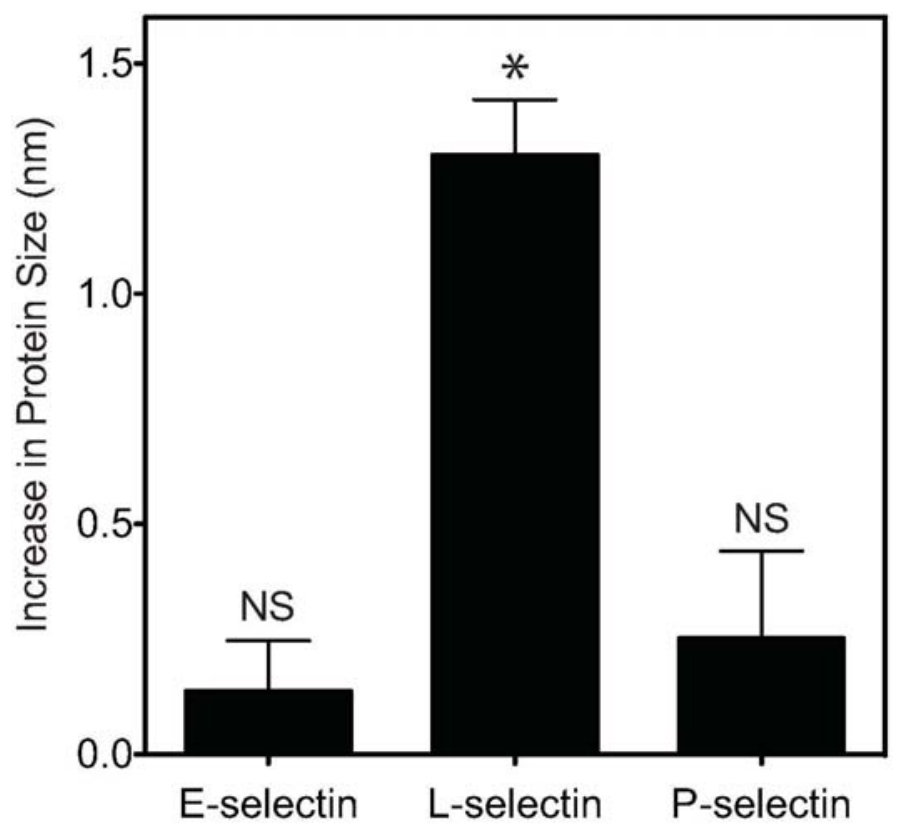

Table 1. Mean particle radius and polydispersity index (PDI) measurements of selectin-coated liposome samples under neutral and acidic conditions. Data reported as mean \pm standard deviation. Results recorded in triplicate.

\begin{tabular}{ccccc}
\hline Lyposome Type & Radius (nm) pH 7.4 & Radius $(\mathbf{n m}) \mathbf{~ p H ~ 6 . 6}$ & PDI pH 7.4 & PDI pH 6.6 \\
\hline PEG only & $52.33 \pm 0.83$ & $52.99 \pm 0.95$ & $0.103 \pm 0.008$ & $0.102 \pm 0.013$ \\
PEG + ES & $74.06 \pm 0.94$ & $74.86 \pm 1.18$ & $0.101 \pm 0.008$ & $0.105 \pm 0.007$ \\
PEG + LS & $61.10 \pm 0.99$ & $63.08 \pm 0.94$ & $0.102 \pm 0.011$ & $0.101 \pm 0.007$ \\
PEG + PS & $83.65 \pm 1.17$ & $84.57 \pm 0.83$ & $0.108 \pm 0.007$ & $0.106 \pm 0.009$ \\
\hline
\end{tabular}

Figure 4. Schematic of increased HSPC adhesion to L-selectin in high affinity, extended conformation under acidic $\mathrm{pH}$ (B) compared to the lower affinity, bent conformation (A).

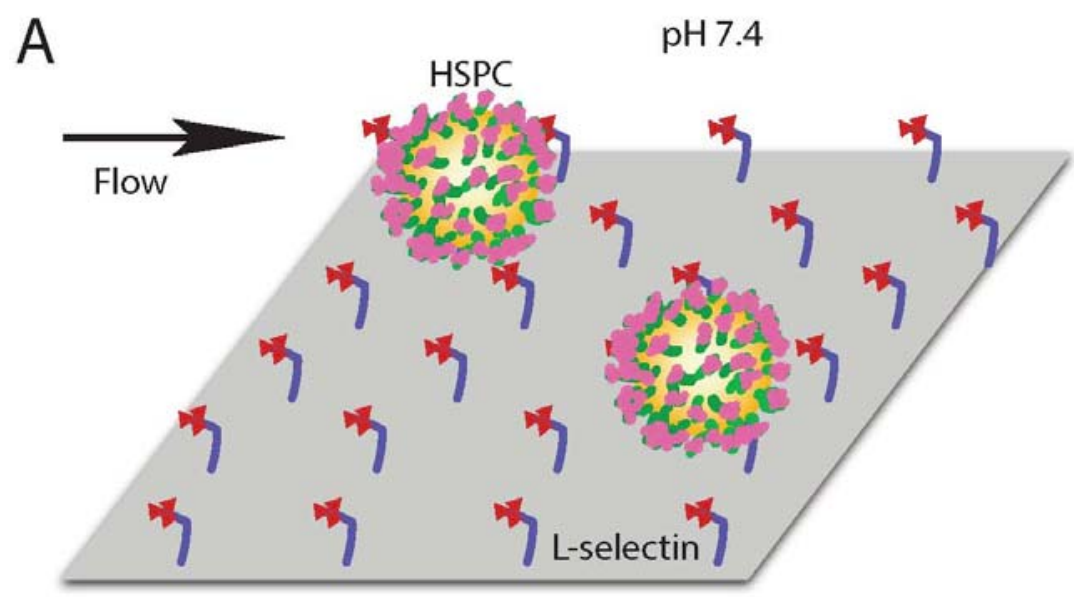


Figure 4. Cont.

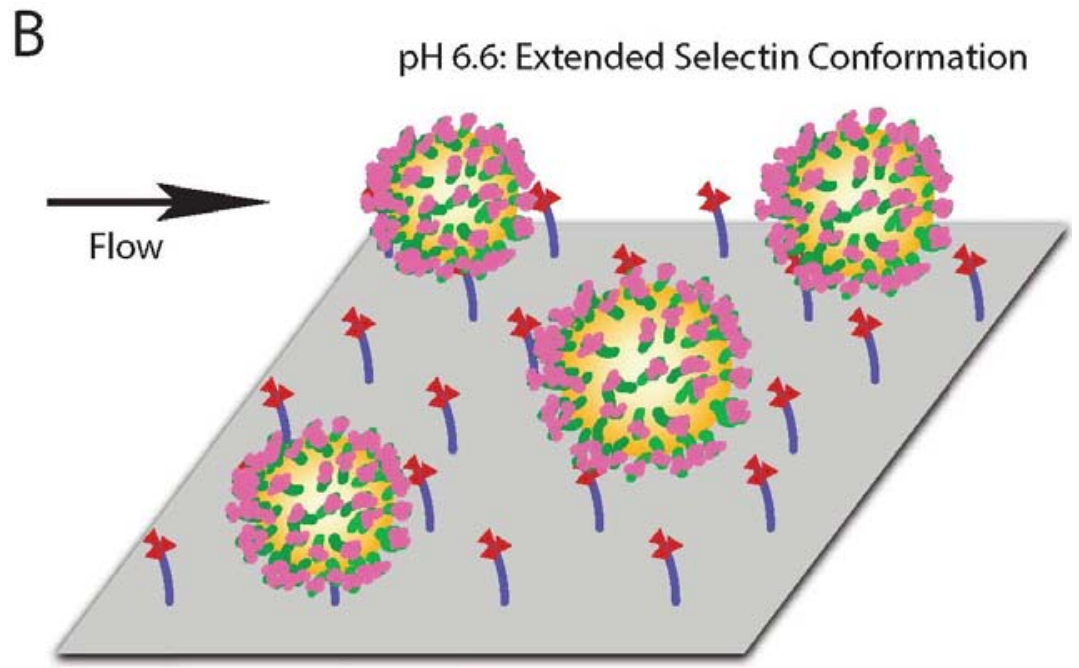

\subsection{L-Selectin Coated-Microtube Captures Human BM CD34+ HSPCs}

Selectin-coated microdevices have been shown to effectively capture viable stem cells [38,39] and circulating tumor cells from whole blood with high yield [40]. To mimic the physiological phenomenon of L-selectin:ligand interaction under acidic conditions for the isolation and enrichment of CD34+ bone marrow cells, low-density bone marrow cells isolated from healthy adult donors using Ficoll were perfused at a concentration $5 \times 10^{6}$ cells $/ \mathrm{ml}$ through L-selectin coated microtubes $(50 \mu \mathrm{g} / \mathrm{mL})$ at $1.0 \mathrm{dyn} / \mathrm{cm}^{2}$ in PBS buffer supplemented with $2 \mathrm{mM} \mathrm{Ca}^{2+}$. Adherent cells were dislodged from the surface using both buffer supplemented with $2 \mathrm{mM}$ EDTA and air embolism. Isolated cells were stained using an anti-CD34 monoclonal antibody. L-selectin coated microtubes were found to capture and enrich CD34+ HSPCs from the bone marrow at $>19 \%$ purity (Figure 5).

Figure 5. L-selectin mediated isolation of CD34+ cells from patient bone marrow samples under acidic pH. Captured cells were labeled using a mouse anti-human CD34 monoclonal antibody. Flow cytometry plots are a representation of experiments done in triplicate. $\mathrm{SSC}=$ side scatter.

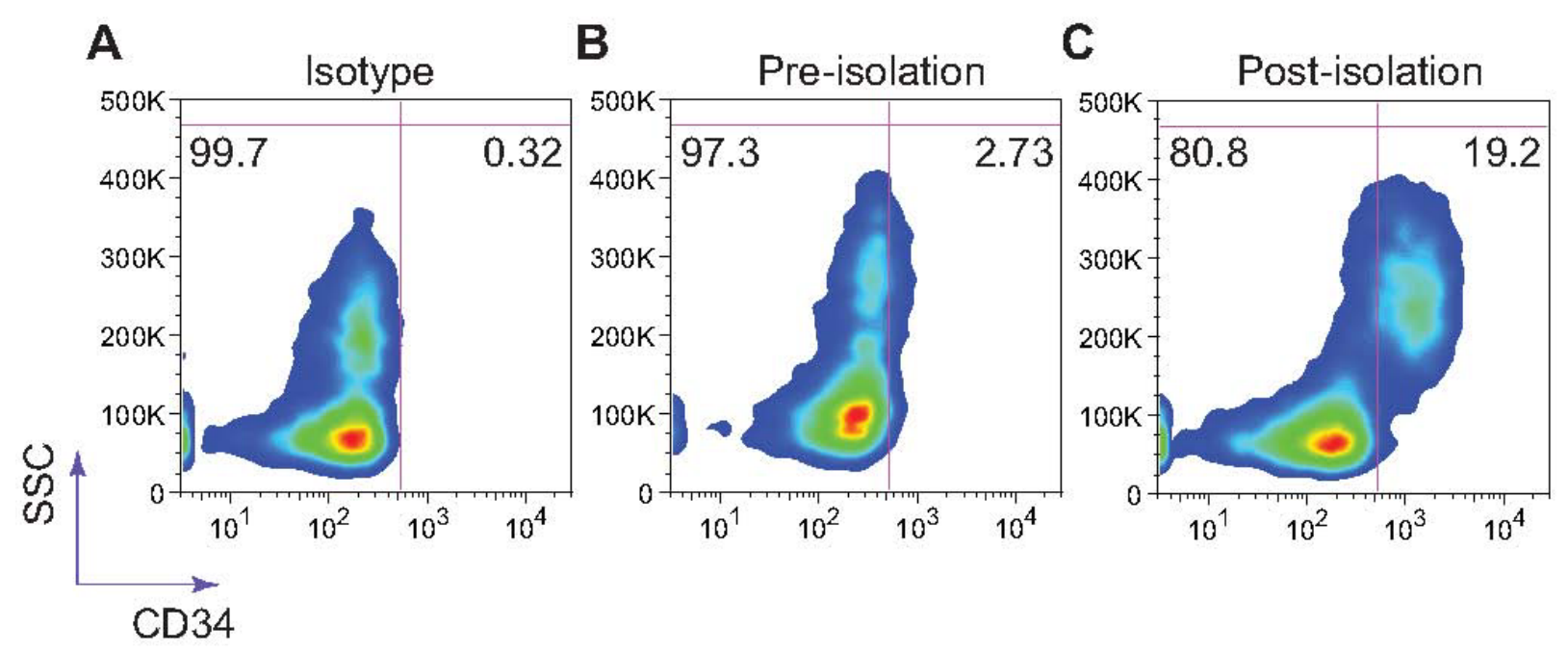




\section{Conclusions}

During tissue inflammation, extracellular $\mathrm{pH}$ can become increasingly acidic. Furthermore, it is also known that HSPCs are recruited to sites of inflammation via selectin-mediated cell rolling. In this study, we showed that acidic extracellular $\mathrm{pH}$ enhances CD34+ HSPCs adhesion to L-selectin, consistent with a measurable extended conformational change of L-selectin to a "high affinity" orientation in acidic $\mathrm{pH}$. This conformational change is taken to increase the frequency of L-selectin:ligand binding. These biophysical insights were applied to the isolation and enrichment of CD34+ HSPCs from bone marrow using an L-selectin coated microtube. The described biomimetic technique allows for both rapid and simple isolation of viable CD34+ HSPCs from patient bone marrow.

\section{Acknowledgments}

The authors gratefully acknowledge Karen Rosell of the University of Rochester for assistance in bone marrow isolation and processing. This work was funded by the National Institutes of Health (grants HL018208 and HL097971).

\section{Conflicts of Interest}

The authors declare no conflicts of interest.

\section{References}

1. Ogawa, M. Differentiation and proliferation of hematopoietic stem cells. Blood 1993, 81, 2844-2853.

2. Kondo, M.; Wagers, A.J.; Manz, M.G.; Prohaska, S.S.; Scherer, D.C.; Beilhack, G.F.; Shizuru, J.A.; Weissman, I.L. Biology of hematopoietic stem cells and progenitors: Implications for clinical application. Annu. Rev. Immunol. 2003, 21, 759-806.

3. Dey, B.R.; Shaffer, J.; Yee, A.J.; McAfee, S.; Caron, M.; Power, K.; Ting, D.T.; Colby, C.; Preffer, F.; Ballen, K.; et al. Comparison of outcomes after transplantation of peripheral blood stem cells versus bone marrow following an identical nonmyeloablative conditioning regimen. Bone Marrow Trans. 2007, 40, 19-27.

4. Dodero, A.; Carniti, C.; Raganato, A.; Vendramin, A.; Farina, L.; Spina, F.; Carlo-Stella, C.; Di Terlizzi, S.; Milanesi, M.; Longoni, P.; et al. Haploidentical stem cell transplantation after a reduced-intensity conditioning regimen for the treatment of advanced hematologic malignancies: Posttransplantation CD8-depleted donor lymphocyte infusions contribute to improve T-cell recovery. Blood 2009, 113, 4771-4779.

5. Chu, S.H.; Heiser, D.; Li, L.; Kaplan, I.; Collector, M.; Huso, D.; Sharkis, S.J.; Civin, C.; Small, D. FLT3-ITD Knockin Impairs Hematopoietic Stem Cell Quiescence/Homeostasis, leading to Myeloproliferative Neoplasm. Cell Stem Cell 2012, 11, 346-358.

6. Zhang, Y.; Yan, X.; Sashida, G.; Zhao, X.; Rao, Y.; Goyama, S.; Whitman, S.P.; Zorko, N.; Bernot, K.; Conway, R.M.; et al. Stress hematopoiesis reveals abnormal control of self-renewal, lineage bias, and myeloid differentiation in Mll partial tandem duplication (Mll-PTD) hematopoietic stem/progenitor cells. Blood 2012, 120, 1118-1129. 
7. Orkin, S.H.; Zon, L.I. Hematopoiesis: An evolving paradigm for stem cell biology. Cell 2008, 132, 631-644.

8. Gordon, M.Y. Adhesive properties of haemopoietic stem cells. Br. J. Haematol. 1988, 68, 149-151.

9. Wright, D.E. Physiological migration of hematopoietic stem and progenitor cells. Science 2001, 294, 1933-1936.

10. Fleming, W.H.; Alpern, E.J.; Uchida, N.; Ikuta, K.; Weissman, I.L. Steel factor influences the distribution and activity of murine hematopoietic stem cells in vivo. Proc. Natl. Acad. Sci. USA 1993, 90, 3760-3764.

11. Smith, A.G. Embryo-derived stem cells: of mice and men. Annu. Rev. Cell Dev. Biol. 2001, 17, $435-462$.

12. Laird, D.J.; von Andrian, U.H.; Wagers, A.J. Stem cell trafficking in tissue development, growth, and disease. Cell 2008, 132, 612-630.

13. Müller, A.M.; Medvinsky, A.; Strouboulis, J.; Grosveld, F.; Dzierzakt, E. Development of hematopoietic stem cell activity in the mouse embryo. Immunity 1994, 1, 291-301.

14. Massberg, S.; Schaerli, P.; Knezevic-Maramica, I.; Köllnberger, M.; Tubo, N.; Moseman, E.A.; Huff, I.V.; Junt, T.; Wagers, A.J.; Mazo, I.B.; et al. Immunosurveillance by hematopoietic progenitor cells trafficking through blood, lymph, and peripheral tissues. Cell 2007, 131, 994-1008.

15. Lee, H.; Ratajczak, M.Z. Innate immunity: A key player in the mobilization of hematopoietic stem/progenitor cells. Arch. Immunol Ther. Exp. 2009, 57, 269-278.

16. Ratajczak, M.Z.; Kim, C.H.; Wojakowski, W.; Janowska-Wieczorek, A.; Kucia, M.; Ratajczak, J. Innate immunity as orchestrator of stem cell mobilization. Leukemia 2010, 24, 1667-1675.

17. Mitchell, M.J.; King, M.R. Computational and experimental models of cancer cell response to fluid shear stress. Front. Oncol. 2013, 3, 1-11.

18. Mitchell, M.J.; King, M.R. Fluid shear stress sensitizes cancer cells to receptor-mediated apoptosis via trimeric death receptors. New J. Phys. 2013, 15, 015008.

19. Dimitroff, C.J. Differential L-selectin binding activities of human hematopoietic cell L-selectin ligands, HCELL and PSGL-1. J. Biolog. Chem. 2001, 276, 47623-47631.

20. Merzaban, J.S.; Burdick, M.M.; Gadhoum, S.Z. Analysis of glycoprotein E-selectin ligands on human and mouse marrow cells enriched for hematopoietic stem/progenitor cells. Blood 2011, $118,1774-1783$.

21. Sultana, D.A.; Zhang, S.L.; Todd, S.P.; Bhandoola, A. Expression of functional P-selectin glycoprotein ligand 1 on hematopoietic progenitors is developmentally regulated. J. Immunol. 2012, 188, 4385-4393.

22. Narasipura, S.D.; Wojciechowski, J.C.; Charles, N.; Liesveld, J.L.; King, M.R. P-Selectin coated microtube for enrichment of CD34+ hematopoietic stem and progenitor cells from human bone marrow. Clin. Chem. 2008, 54, 77-85.

23. Mitchell, M.J.; King, M.R. Shear-induced resistance to neutrophil activation via the formyl peptide receptor. Biophys. J. 2012, 102, 1804-1814.

24. Cao, T.M.; Takatani, T.; King, M.R. Effect of extracellular pH on selectin adhesion: Theory and experiment. Biophys. J. 2013, 104, 292-299. 
25. Trevani, A.S.; Andonegui, G.; Giordano, M.; López, D.H.; Gamberale, R.; Minucci, F.; Geffner, J.R. Extracellular acidification induces human neutrophil activation. J. Immunol. 1999, 162, 4849-4857.

26. Lardner, A. The effects of extracellular $\mathrm{pH}$ on immune function. J. Leukoc. Biol. 2001, 69, 522-530.

27. Cook, D.N. The role of MIP-1 alpha in inflammation and hematopoiesis. J. Leukoc. Biol. 1996, 59, 61-66.

28. Mourkioti, F.; Rosenthal, N. IGF-1, inflammation and stem cells: Interactions during muscle regeneration. Trend. Immunol. 2005, 26, 535-542.

29. Amselem, S.; Cohen, R.; Druckmann, S.; Gabizon, A.; Goren, D.; Abra, R.M.; Huang, A.; New, R.; Barenholz, Y. Preparation and characterization of liposomal doxorubicin for human use. J. Liposome Res. 1992, 2, 93-123.

30. Haran, G.; Cohen, R.; Bar, L.; Barenholz, Y. Transmembrane ammonium sulfate gradients in liposomes produce efficient and stable entrapment of amphipathic weak bases. Biochim. Biophys. Acta 1993, 1151, 201-215.

31. Mitchell, M.J.; Chen, C.S.; Ponmudi, V.; Hughes, A.D.; King, M.R. E-selectin liposomal and nanotube-targeted delivery of doxorubicin to circulating tumor cells. J. Contr. Release 2012, 160, 609-617.

32. Mitchell, M.J.; Castellanos, C.A.; King, M.R. Nanostructured surfaces to target and kill circulating tumor cells while repelling leukocytes. J. Nanomater. 2012, 2012, 1-10.

33. Huang, Z.; King, M. An immobilized nanoparticle-based platform for efficient gene knockdown of targeted cells in the circulation. Gene Therapy 2009, 16, 1271-1282.

34. Lawrence, M.B.; Springer, T.A. Neutrophils roll on E-selectin. J. Immunol. 1993, 151, 6338-6346.

35. Bevilacqua, M.P.; Nelson, R.M. Selectins. Clin. Invest. 1993, 91, 379-387.

36. Greenberg, A.W.; Kerr, W.G.; Hammer, D.A. Relationship between selectin-mediated rolling of hematopoietic stem and progenitor cells and progression in hematopoietic development. Blood 2000, 95, 478-486.

37. Phan, U.T.; Waldron, T.T.; Springer, T.A. Remodeling of the lectin-EGF-like domain interface in $\mathrm{P}$ - and L-selectin increases adhesiveness and shear resistance under hydrodynamic force. Nat. Immunol. 2006, 7, 883-889.

38. Wojciechowski, J.; Narasipura, S.; Charles, N.; Mickelsen, D.; Rana, K.; Blair, M.; King, M. Capture and enrichment of CD34-positive haematopoietic stem and progenitor cells from blood circulation using P-selectin in an implantable device. Br. J. Hematol. 2008, 140, 673-681.

39. Charles, N.; Liesveld, J.L.; King, M.R. Investigating the feasibility of stem cell enrichment mediated by immobilized selectins. Biotechnol. Prog. 2007, 23, 1463-1472.

40. Hughes, A.D.; Mattison, J.; Powderly, J.D.; Greene, B.T.; King, M.R. Rapid isolation of viable circulating tumor cells from patient blood samples. JoVE 2012, 64, e4248-e4248.

(C) 2013 by the authors; licensee MDPI, Basel, Switzerland. This article is an open access article distributed under the terms and conditions of the Creative Commons Attribution license (http://creativecommons.org/licenses/by/3.0/). 